Update Article

\title{
Homeopathy and Collective Health: The Case of Dengue Epidemics
}

\author{
Renan Marino (MSc) \\ Faculty of Medicine of São José do Rio Preto, FAMERP, São Paulo, Brazil
}

\begin{abstract}
This paper describes experiences of the use of homeopathy in the prevention and treatment Dengue fever in São José do Rio Preto, São Paulo, Brazil. May 2001, a single dose of the homeopathic remedy Eupatorium perfoliatum $30 \mathrm{cH}$ was given to $40 \%$ of residents of the most highly affected neighborhood. Thereafter, Dengue incidence decreased by $81.5 \%$, a highly significant decrease as compared with neighborhoods that did not receive homeopathic prophylaxis $(\mathrm{p}<0.0001)$. Between April and September 2007, a homeopathic complex composed of Eupatorium perfoliatum, Phosphorus and Crotalus horridus 30cH, given to 20,000 city residents. This trial was aborted prematurely due to national political intervention; therefore, only partial and isolated data could be recorded. However, the results suggest that homeopathy may be effective in the prevention and treatment of Dengue epidemics.
\end{abstract}

Keywords: Homeopathy; public health; Epidemic; Dengue

\section{Introduction}

Since its discovery and throughout its colonial period, Brazil has been the stage for countless epidemic diseases. Even today, the country faces immense challenges posed by yellow fever, Dengue, cholera, Chagas' disease and, more recently, AIDS, in addition to the reemergence of tuberculosis. Nevertheless, over the last 50 years the country's health indexes have improved remarkably. Also, causes of mortality have changed dramatically. In recent years, the leading causes of death are no longer infectious diseases, but rather chronic diseases associated with heart diseases and cancer, along with a worrisome increase in external causes such as accidents and homicide. Notwithstanding, the main challenge to the national health system is the return of endemic and epidemic diseases long held as controlled. The potential severity of Dengue epidemics in Brazil is due to the reintroduction of Aedes aegypti in the 1970s, with successive outbreaks of the disease, including cases of Dengue hemorrhagic fever (DHF) [1].

In spite of its rigorous attention to the individuality of each patient, homeopathy can be used in epidemics. Hahnemann, the founder of homeopathy, stated that an accurate observation of cases in an epidemic disease allows the physician to find the homeopathically most suitable remedy corresponding to the "totality of symptoms" of the outbreak [2].
The analysis of the signs and symptoms found in the affected population (genus epidemicus) would correspond precisely to the symptom analysis performed in the individual. Hahnemann noted that the peculiar character of an epidemic disease leads to the discovery of the remedy specific to it, which may then be used to treat the population at large.

This hypothesis has been confirmed in practice, as illustrated by the cholera epidemics in Europe (1831-1834) [3] and the epidemics of typhus (19251926) in Bahia, Brazil [4]. A more recent example was the use of Meningococcinum $10 \mathrm{cH}$ in single dose as preventive of meningitis by Meningococcus in Guaratinguetá, São Paulo, in August 1974 [5]. Outcomes pointed out to the effectiveness of the use of this nosode, as the incidence of the disease ranked among the lowest in the State.

In 1985, homeopathy was included among the therapeutic options offered at the outpatient facilities of the Brazilian public health system, the under rapid expansion [6]. Nevertheless, material and qualified human resources are still insufficient at the public level, including a lack of programs warranting the population wide and free access to homeopathic remedies. Similarly, homeopathy still needs to be integrated into the various levels of health care management.

The present paper describes our field experience using homeopathy for prevention and treatment of Dengue fever outbreaks in São José de Rio Preto, 
São Paulo, Brazil, in May 2001 and April September 2007.

\section{Dengue fever}

Dengue is an acute and severe febrile disease. Fever is attended by prostration, chills, intense headache, retro-ocular pain, muscular and joints pain. Nausea, vomiting, sore throat and adenopathy may be found. In the classic form (Dengue fever - DF), death is rare, however in the hemorrhagic version (Dengue Hemorrhagic Fever- DHF), mortalitity is high, especially in children [7]. The incubation period is 5 to 8 days. Aedes aegypti, the most common vector in the Americas, reproduces easily in stagnant waters. The etiologic agent is a RNA-virus genus flavivirus, family Togaviridae, presenting different serotypes; immunity elicited by the disease is serotype-specific [7].

Diagnosis of Dengue is based upon epidemiological and clinical data. The virus may be isolated from blood during the first days of the disease; serological tests include hemagglutination inhibition, complement fixation and seroneutralization. Prevention is limited to the combating Aedes aegypti; vaccination is not yet available [8]. In an interview to the International Herald Tribune in September $25^{\text {th }}$ 2005, David Gubler, a senior adviser for infectious diseases transmitted by vectors to the American Centers for Disease Control and
Prevention (CDC) stressed that much is still unknown about the virus; the existence of 4 varieties of it makes difficult to produce an effective vaccine. While several vaccines are under trials that may take several years to complete, the focus has shifted to the mapping of the virus genome in order to develop drugs able to inhibit its replication in human beings [9]. Considering estimates by World Health Organization (WHO) that Dengue affects at least 50 million people/year on six continents, it might be inferred that Dengue epidemics have increased in extension and virulence, possibly indicating viral mutation and evolution [7].

Therefore, in the short run the only resource to face outbreaks of the disease is the control of the mosquito population. In this regards, both species of vector - Aedes aegypti and Aedes albopictus - have shown remarkable adaption to urban environments and immunity to insecticides [7].

Homeopathic prophylaxis of Dengue fever, São José do Rio Preto, São Paulo, 2001

Our experience began in 2001, when the homeopathic remedy Eupatorium perfoliatum in dilution $30 \mathrm{cH}$ was used in single doses to prevent Dengue fever. The remedy was chosen by applying the principles of epidemic genus. The protocol for the study of epidemic genus is described in Figure 1.

\section{Figure 1. Protocol for study of epidemic genus}

\footnotetext{
1- Homeopathic clinical examination of the first 20 cases of the epidemic outbreak.

2- Hierarchization of the set of most significant symptoms (epidemic genus, corresponding in the collective level to the individual minimum syndrome of maximum value or Inbegriff).

3- Repertory analysis.

4- "Hughes' filter": critical analysis of repertory analysis results through comparison to the materia medica through a physiopathological filter in order to establish strict concordance between the remedy image and the epidemics image (epidemic genus).

5- Steady monitorizing of epidemic genus features.
}

The study was conducted in the Cristo Rei area, the neighborhood with the highest incidence of Dengue in São José do Rio Preto in May 2001 [10]. At the time, 4,850 residents lived in the neighborhood. The remedy of the epidemic genus was chosen from symptoms obtained in patients residing in the same neighborhood between March and April 2001 with confirmed diagnosis of Dengue. (Table 1)

The study of the materia medica of Eupatorium perfoliatum confirms that pathogenetically, the remedy corresponds to a true specific for Dengue [11]:
- Very restless; cannot keep still, though wishes to, mainly during fever and chills.

- Anxious, full of complaints and prostrated during fever.

- Much yawning before and during chills, with no relief.

- Would like to rest, lying down, but cannot, as feels each bone sore, beaten, blown. 
- Relief by the least possible rest, as it prevails anxious restlessness with aching in all the body.

- Also ameliorates by heat, talking, staying at home and supporting on hands and knees, also by sinking the face in the pillow.

- Chills beginning in the stomach; dry skin, which almost does not perspire; when it does, perspiration minimally ameliorates the general feeling but does not relieve headache at all.

- Important remedy in acute hepatitis: hepatic congestion, colicky pain in the upper part of the abdomen; when coughing or moving, epigastrium is very sensitive. Nausea when smelling or looking at food; bilious vomiting; gastralgia after eating, ameliorates only after vomiting.

Table 1. Repertory analysis of symptoms of Dengue (Radar 5.0)

\begin{tabular}{|l|c|c|c|c|c|c|c|c|c|c|c|c|c|}
\hline & $\begin{array}{c}\text { Eup- } \\
\text { per }\end{array}$ & Hep & Sep & Sulph & Ars & Bov & Bry & $\begin{array}{c}\text { Calc- } \\
\text { p }\end{array}$ & $\begin{array}{c}\text { Nat- } \\
\mathrm{m}\end{array}$ & $\begin{array}{c}\text { Nux- } \\
\mathrm{v}\end{array}$ & Puls & Verat & Zinc \\
\hline $\begin{array}{l}\text { Generalities; } \\
\text { Pain; broken; } \\
\text { bones as if }\end{array}$ & $\mathbf{3}$ & 1 & 1 & 1 & 1 & 1 & 2 & 1 & 2 & 1 & 1 & 2 & 1 \\
\hline $\begin{array}{l}\text { Stomach; } \\
\text { Thirst; chill; } \\
\text { before }\end{array}$ & $\mathbf{3}$ & 2 & 1 & 1 & $\mathbf{3}$ & - & - & - & 1 & 2 & $\mathbf{3}$ & - & - \\
\hline $\begin{array}{l}\text { Head; } \\
\text { Pain; } \\
\text { pulsating }\end{array}$ & 2 & 2 & 2 & $\mathbf{3}$ & 2 & 1 & 1 & 2 & $\mathbf{3}$ & 2 & $\mathbf{3}$ & 1 & 1 \\
\hline $\begin{array}{l}\text { Stomach; } \\
\text { Nausea; } \\
\text { motion, on }\end{array}$ & 2 & 1 & 1 & 1 & - & 1 & 2 & 1 & - & - & - & 2 & 2 \\
\hline $\begin{array}{l}\text { Eye; Pain; } \\
\text { sore }\end{array}$ & $\mathbf{3}$ & 2 & 1 & 2 & 2 & 1 & 2 & 2 & 2 & 2 & $\mathbf{3}$ & 1 & 1 \\
\hline
\end{tabular}

Table 2. Report of confirmed cases of Dengue before and after homeopathic intervention

\begin{tabular}{|l|l|l|l|}
\hline Neighborhood & $\begin{array}{l}1 / 1 / 01- \\
4 / 5 / 01\end{array}$ & $\begin{array}{l}5 / 5 / 01- \\
31 / 12 / 01\end{array}$ & $\begin{array}{l}\text { Decrease } \\
(\%)\end{array}$ \\
\hline Cristo Rei & 142 & 26 & 81.5 \\
\hline São Diocleciano & 62 & 26 & 58 \\
\hline Vila Toninho & 82 & 50 & 39 \\
\hline $\begin{array}{l}\text { Gonzaga de } \\
\text { Campos }\end{array}$ & 51 & 32 & 37 \\
\hline Cecap & 10 & 9 & 10 \\
\hline
\end{tabular}

1,959 individuals (40.2\%) took the homeopathic remedy. Comparative incidence of Dengue among several neighborhoods of São José do Rio Preto before and after the homeopathic intervention is shown in Table 2.

The data is presented as a fall factor diagram. (Figure 2). Fall factor was proposed by Cordeiro [12] for the statistical evaluation of the analysis of dependence of the later progression of the epidemics of Dengue. After the homeopathic intervention, relative to the other neighborhoods under study, Cristo Rei occupies the upper left quadrant in the diagram, representing the highest fall in the occurrence of new cases of Dengue in the period under study. 
Figure 2. Fall Factor Diagram
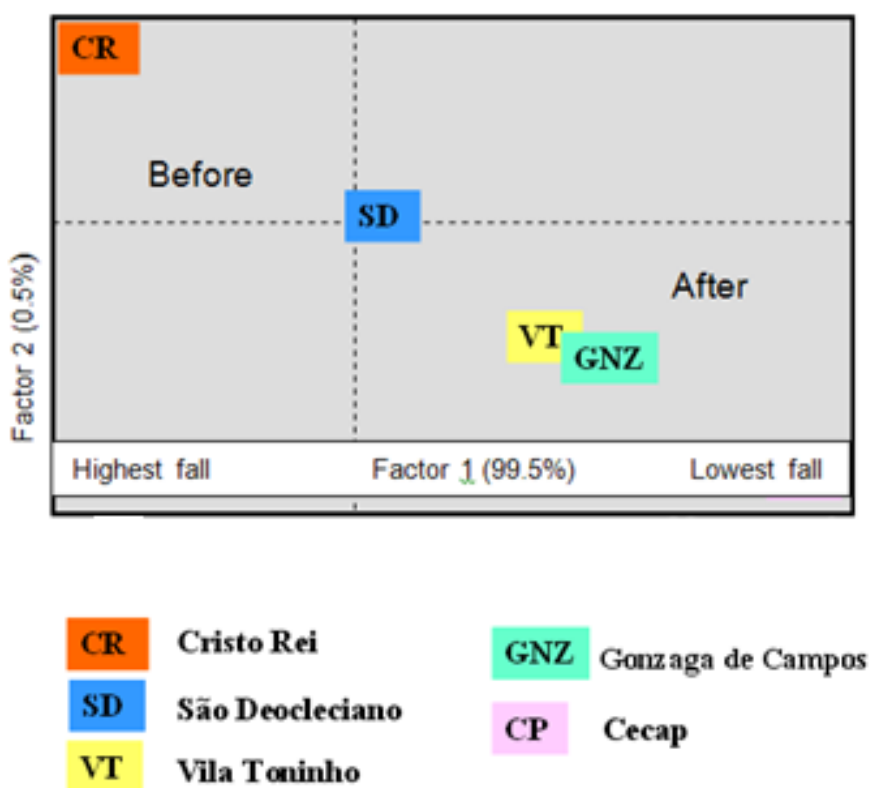

"Fall factor" compare rate of decline in five neighborhoods in São José do Rio Preto. Greater declines are closer to the upper left corner. The decline in Cristo Rei was significantly greater than in other neighborhoods $(\mathrm{p}<0.0001)$.

Decrease in the number of cases in the neighborhoods considered between the first period (incidence of Dengue from January $1^{\text {st }}$ to May $4^{\text {th }}$ 2001) and the second period (reported cases from May $5^{\text {th }}$ to December $31^{\text {st }} 2001$ ) dramatically demonstrates the fall in incidence in Cristo Rei area. The fall factor diagram graphically represents the prominence of this figure when compared to controls, indicating a strong association between the homeopathic procedure employed and outcomes. This difference between Cristo Rei and control neighborhoods is highly significant $(p<0.0001)$. This paper does not examine biases or factors that may have confounded this association.

\section{Homeopathic prophylaxis and treatment of Dengue fever, São José do Rio Preto, 2007}

In March 2007, facing an aggravation of the epidemiological status of Dengue in São José do Rio Preto and neighboring counties, the Municipal Secretary of Health and Hygiene (SMSH) decided to implement actions indicated in Ruling MS/GM No 971 from May $3^{\text {rd }} 2006$ by the national Ministry of Health, known as Política Nacional de Prácticas Integrativas e Complementares (PNPIC - National Policy for Integrative and Complementary Practices) for the national public health system (Sistema Único de Saúde - SUS).

In this context, a homeopathic complex composed of Eupatorium perfoliatum, Phosphorus and Crotalus horridus - all in dilution $30 \mathrm{cH}$, in a single dose of 2 drops p.o. - was administered for Dengue prevention, It was hoped that such prophylaxis would attenuate the intensity of symptoms of Dengue and prevent hemorrhagic complications.

The choice of the remedies was based on homeopathic pathogenetic information [13]: Williamson \& Neidhard's 1846 proving of Eupatorium perfoliatum - a plant native to the East of the USA, employed by aborigines to treat "breaking-bones fever"; Hahnemann's 1828 proving of Phosphorus and Hering's 1837 proving of the venom of North American rattlesnake (Crotalus horridus).

The option for a complex of remedies was determined by the epidemiological profile of Dengue in São José do Rio Preto: initially, thousands of patients had been affected by serotypes 1 and 2 . Later a large number of the more severe forms of the disease began to appear, related to serotype 3 . In this situation, we realized that the outbreak was actually an epidemiological mosaic, symptomatically corresponding to the associated materia medica of the homeopathic remedies Eupatorium perfoliatum, Phosphorus and Crotalus horridus. While traditionally, homeopathy indicates the use of single remedies, relevant authorities have remarked that the use of complexes is particularly suitable in epidemics; moreover, that when the components of a complex are complementary, their individual actions are not only maintained, but even potentiated [14].

Eupatorium perfoliatum represents the typical clinical picture of classic Dengue, while Phosphorus, due to its affinity for the liver, has effects on the functional integrity of this organ and on the production of coagulation factors. Crotalus horridus corresponds well with the clinical picture of DHF. It 
is worthy of mention that, histopathologically, Dengue fever always involves some degree of viral hepatitis [15].

From March $15^{\text {th }}$ to $22^{\text {nd }} 2007,20,000$ doses of homeopathic complex against Dengue were administered to the population of São José do Rio Preto, in accordance with the Health Secretary program explicitly aimed at including this resource in the ongoing fight to combat Dengue fever.

Community health agents were trained to perform an archive search in order to determine the neighborhood with the highest number of patients receiving homeopathic Dengue prophylaxis (figure 4). Our sources included records of patients receiving homeopathic complex at public outpatient clinics (Unidades Básicas de Saúde - UBS) between March $15^{\text {th }}-22^{\text {nd }} 2007, \quad$ Programa SISP Ambulatorial (record of individuals), and SINAN (Sistema de Informação de Agravos de Notificação Information System of Aggravation of Reporting). The incidence of positive cases of Dengue in 2007 is described in Table 3.

771 individuals who took the homeopathic complex as preventive were included in the study. From them, $524(68 \%)$ could be located. From this group, 384 (73.4\%) did not have Dengue . Of 140 (26.6\%) that had Dengue , 40 were given the homeopathic complex therapeutically, i.e. 3 daily doses for one week. (Table 4)

Figure 4. São José do Rio Preto, administrative areas (poles). Population (2007): 424,114.

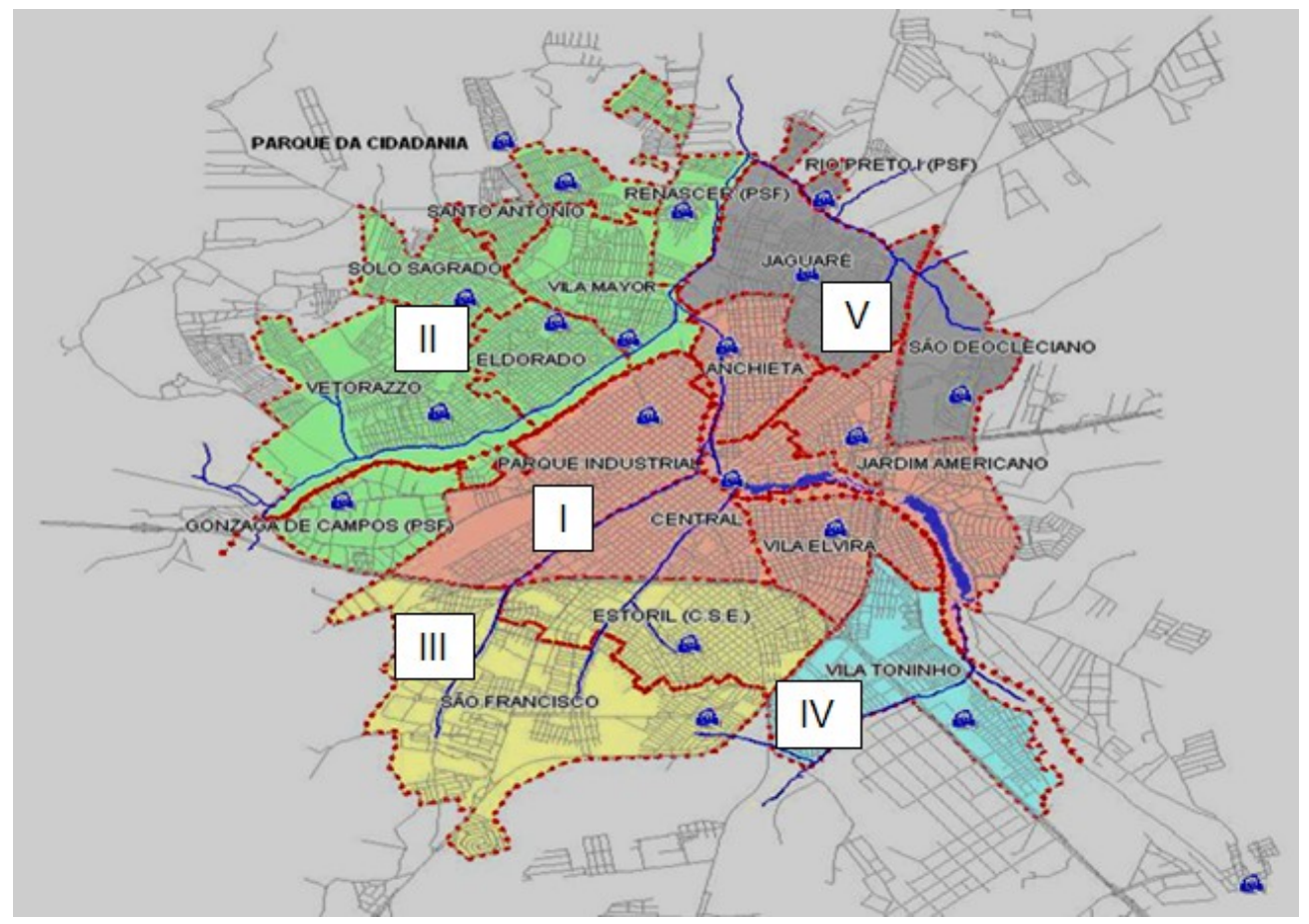

Table 3. Positive cases of dengue in São José do Rio Preto, 2007, according to month of onset of symptoms and diagnostic criteria.

\begin{tabular}{|l|r|l|l|l|r|r|r|r|r|r|r|r|r|}
\hline $\begin{array}{c}\text { Diagnostic criteria / } \\
\text { Month }\end{array}$ & Jan & Feb & Mar & Apr & May & Jun & Jul & Aug & Sep & Oct & Nov & Dec & Total \\
\hline Laboratorial & 158 & 474 & 1,253 & 573 & 159 & 8 & 3 & 9 & 7 & 5 & 16 & 9 & 2,674 \\
\hline $\begin{array}{l}\text { Clinical- } \\
\text { epidemiological }\end{array}$ & 57 & 602 & 1,566 & 2.979 & 1.566 & 369 & 105 & 50 & 61 & 9 & 16 & 1 & 7,381 \\
\hline Total & 215 & 1,076 & 2,819 & 3.552 & 1.725 & 377 & 108 & 59 & 68 & 14 & 32 & 10 & $\mathbf{1 0 , 0 5 5}$ \\
\hline
\end{tabular}

Table 4. Distribution by age and gender of individuals who took homeopathic complex against Dengue as preventive. 


\begin{tabular}{|l|c|c|c|c|c|c|}
\hline $\begin{array}{l}\text { Age } \\
\text { (years) }\end{array}$ & \multicolumn{2}{|l|}{$\begin{array}{l}\text { Did not have } \\
\text { Dengue }\end{array}$} & \multicolumn{2}{l|}{$\begin{array}{l}\text { Had Dengue and took homeopathic } \\
\text { complex as curative }\end{array}$} & $\begin{array}{l}\text { Had Dengue and did not take } \\
\text { homeopathic complex as curative }\end{array}$ \\
\hline Gender & Male & Female & Male & Female & Male & Female \\
\hline$\leq 20$ & 33 & 40 & 4 & 3 & 11 & 8 \\
\hline $21-30$ & 8 & 25 & 3 & 1 & 2 & 11 \\
\hline $31-40$ & 11 & 33 & 5 & 2 & 5 & 9 \\
\hline $41-50$ & 21 & 49 & 1 & 5 & 4 & 8 \\
\hline $51-60$ & 22 & 42 & 1 & 6 & 7 & 9 \\
\hline$>60$ & 41 & 59 & 2 & 7 & & 100 \\
\hline Total & \multicolumn{2}{|c|}{384} & & 40 & & 9 \\
\hline
\end{tabular}

Figure 5. Relative frequency of symptoms among patients that took homeopathic complex as preventive and had Dengue .

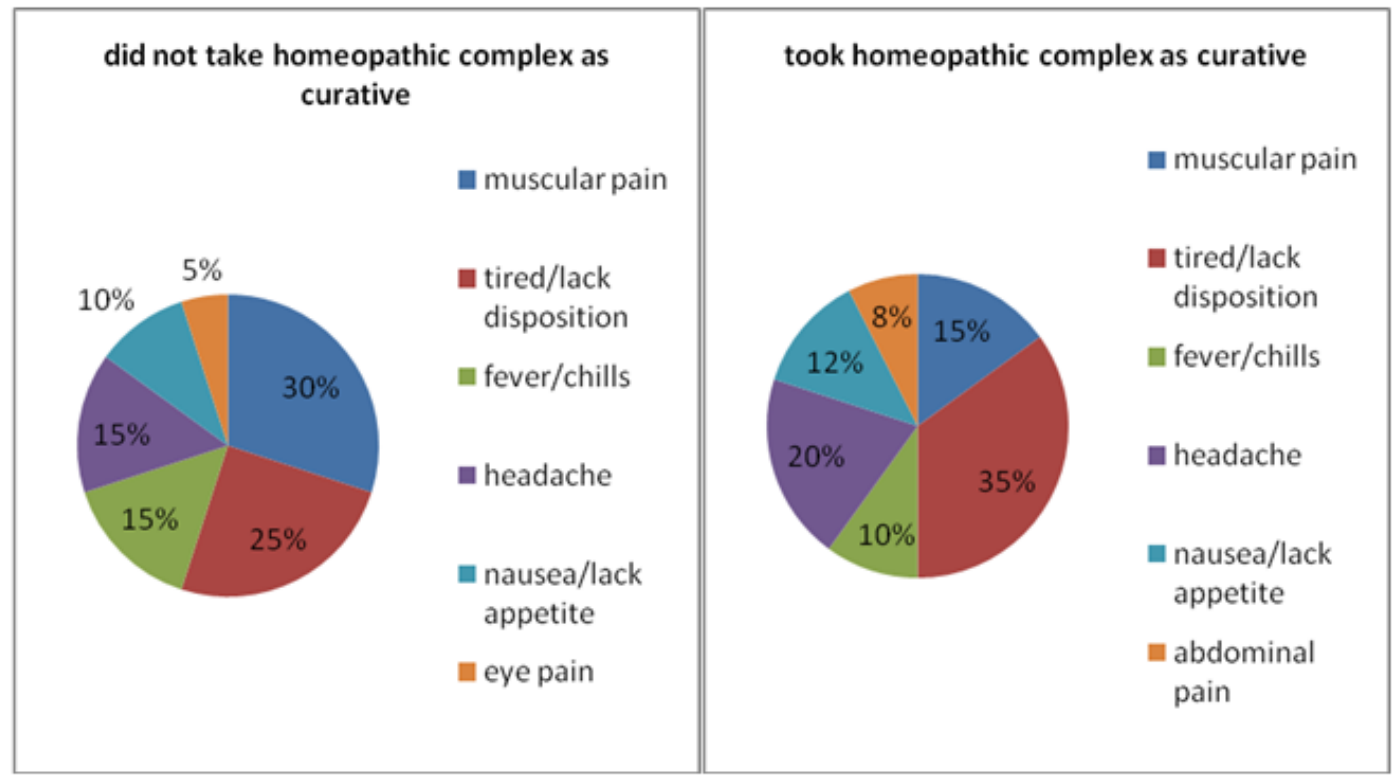

Among those that took the homeopathic complex prophylactically and had Dengue, the symptoms were: muscular pain $(30 \%)$, tiredness and lack of disposition (25\%), fever and chills (15\%), headache $(15 \%)$, nausea and lack of appetite $(10 \%)$ and retroocular pain $(5 \%)$. The relative frequency of symptoms was different among those who also took homeopathic complex as curative: tiredness and lack of disposition (35\%), headache (20\%), muscular pain $(15 \%)$, nausea and lack of appetite (12.5\%), fever and chills (10\%) and abdominal pain (7.5\%). (Figure 5)

Among individuals who took homeopathic complex as preventive and had Dengue, convalescence lasted up to one week in $39 \%$, up to 2 weeks in $42 \%$ and more than 2 weeks in $19 \%$, so that convalescence lasted up to 2 weeks in $81 \%$. Among individuals that also took homeopathic complex as curative, respective distribution was $40 \%, 53 \%$ and $8 \%$, so that convalescence lasted up to 2 weeks in $92 \%$.

\section{Epilogue}

The use of the homeopathic complex was restricted to one single week in March 2007 due to a disagreement between the State and Municipal Secretaries of Health giving rise to a serious institutional crisis widely reported by Brazilian media, creating feelings of doubt and confusion among the population. This situation also seriously impeded our research, limiting us to a small sample and inadequate controls. In spite of this, we were able to collect interesting data that may contribute to the ongoing efforts to control Dengue in Brazil. Unfortunately, in the 2007 outbreak of Dengue in São José de Rio Preto, a consensus in April 15 th 
among representatives of the National Health Ministry, the State Health Secretary and the Municipal Health Secretary suspended prophylactic administration of the homeopathic complex, a decision upheld by the Ministry of Justice.

However, as Jacques Monod would have it, quoting Democritus: "chance always goes together with necessity" [16]. The large scale use of a homeopathic complex in Dengue prophylaxis is a remarkable $21^{\text {st }}$ century public health experiment. In light success this approach in the 2007 Macaé, Rio de Janeiro outbreak [17-18], it is lamentable that political constraints aborted this pioneering effort before it could be completed.

\section{References}

[1] Rouquayrol MZ, Almeida Filho N. Epidemiologia \& saúde. $6^{\text {th }}$ ed. Rio de Janeiro: Medsi; 2003.

[2] Hahnemann S. Organon da arte de curar. $6^{\text {th }}$ ed. Ribeirão Preto: Museu de Homeopatia Abrahão Brickmann; 1995.

[3] Ullman D. Homeopatia: medicina para o século XXI. São Paulo: Cultrix; 1988.

[4] Galhardo JER. I Congresso Brasileiro de Homeopatia. Rio de Janeiro: Instituto Hahnemanniano do Brasil; 1928.

[5] Castro D. Homeopatia e profilaxia. São Paulo: Cultrix; 1988.

[6] Brasil, Ministério da Saúde. A homeopatia que queremos implantar no SUS. Brasília: Grupo de Trabalho para a Elaboração da Política Nacional das Medicinas Naturais e das Práticas Complementares - Subgrupo de Homeopatia. 2004.

[7] Marino R. Homeopatia em saúde coletiva: contribuição ao estudo de epidemias [Dissertation (MSc)]. São José do Rio Preto: Faculdade de Medicina de São José do Rio Preto; 2006.

[8] Amato Neto V, Baldy JLS. Doenças transmissíveis. São Paulo: Sarvier; 1991.
[9] Arnold W. Emergency measures set on Dengue fever. International Herald Tribune [newspaper online]. 2005 Sep 28 [cited 2008 Nov 01]. Available from:

http://www.nytimes.com/2005/09/28/world/asia/28iht -fever.html? r=1.

[10] Marino R, Jamal EM, Esteves Neto SH, Constantino A, Braguini VR. Emprego profilático da homeopatia em uma epidemia de Dengue. Pesq Homeopát/Homeop Esplor. 2003; 18(2): 2-6.

[11] Hughes R, Dake JP. Cyclopaedia of drug pathogenesy. London/New York: British Homeopathic Society/Boericke \& Tafel; 1888.

[12] Cordeiro JA. Análise de dependência: uma técnica para estudo de tabelas cruzadas [Thesis (Livre Docência)]. São José do Rio Preto: UNESP; 1990.

[13] Soares AAD. Dicionário de Medicamentos Homeopáticos. São Paulo: Livraria Santos Editora; 2000.

[14] Pozetti G L. Complexos e complexismos. Ribeirão Preto: IHFL; 1993.

[15] Migowski E. Uso de antitérmicos em doenças infecciosas virais. São Paulo: Abbott do Brasil; 2002.

[16] Monod J. O acaso e a necessidade. $4^{\mathrm{a}}$ ed. Petrópolis: Vozes: 1989.

[17] Nunes LAS. Contribuição da homeopatia ao controle da epidemia de Dengue no município de Macaé, Rio de Janeiro. Proceedings of the IX Simpósio Nacional de Pesquisas em Homeopatia (SINAPIH)/9 $9^{\text {th }}$ Research International Meeting in Homeopathy (RIM-H); 2008 May 1-3; Rio de Janeiro, Brasil. Rio de Janeiro: UERJ; 2008. p 1322.

[18] Nunes LAS. Contribution of homeopathy to the control of an outbreak of dengue in Macaé, Rio de Janeiro. Int J High Dilution Research [online]. 2008 [cited 2008 Dec 19]; 7(25): 186-192. Available from: http://www.feg.unesp.br/ ojs/index.php/ijhdr/article/ view/315/374.

\section{(cc) BY-NC-ND Licensed to GIRI}

Support: author declares that this study received no funding

Conflict of interest: author declares there is no conflict of interest

Received: 10 November 2008; Revised 10 December 2008; Published: 19 December 2008

Erratum: 30 Dec 2008. (http://www.feg.unesp.br/ ojs/zacha_ijhdr/erratum/?v=7\&i=25\&pi=179)

Correspondence author: Renan Marino, renanmarino@uol.com.br

How to cite this article: Marino R. Homeopathy and Collective Health: The Case of Dengue Epidemics. Int J High Dilution Res [online]. 2008 [cited YYYY Mmm DD]; 7(25): 179-185. Available from:

http://www.feg.unesp.br/ ojs/index.php/ijhdr/article/view/312/373. 